\title{
IMPACT OF ROAD INFRASTRUCTURE PRICING ON TRANSPORT PLANNING
}

The paper deals with an issue of the impact of road infrastructure pricing on transport planning. The first part describes the history of road infrastructure pricing in the USA and the EU. The paper also describes an applicable methodology of toll rate determination in the EU. Further part of the paper deals with the factors affecting decision-making of carriers while planning a route of transport. Especially, it deals with a value of time savings and savings in fuel costs while deciding among several routes of transport. The proposal of a methodology for toll rate determination, taking into account the value of time savings for a carrier while using the toll road infrastructure, is elaborated in the next part of the paper. The methodology also takes into account savings in fuel costs of carriers.

Keywords: Transport, toll, financing, factor, impact, decision-making.

\section{Introduction}

Methods of road pricing are significantly changing in Europe in recent years. Most states have substituted the method of road charging in the form of vignettes for the performance-based method of road pricing. In the case of the performance-based method of road pricing, the fee amount does not depend on time validity of vignettes but it depends on the actual distance travelled within toll road infrastructure [1]. Since 2005, the method of road network pricing has been changed, for example, in Germany, Austria, the Czech Republic, the Slovak Republic, and Hungary. Changes in the system of road pricing can be also observed in non-EU states (e.g. Belarus). Under this method of road pricing, road transport operators (carriers) usually bear higher costs for using road network, and they can also consider a possibility to use non-tolled road infrastructure when planning transport or to use roads with lower fees [2]. The amount of fees for using road infrastructure is regulated by Directive 1999/62/EC in the European Union. The Directive provides a methodology for calculating fees for using road infrastructure without consideration of the possibility of using a parallel non-tolled road by the carrier [3]. When charging road infrastructure, there are also approaches that take into account a decision-making process from the position of carriers. Such approaches are addressed by several authors, for example, Vadali et al. (2007) [4]. The objective of this paper is to show the impact of road infrastructure pricing on a decision-making process of carriers while planning a route of transport. The objective is also to elaborate a methodology for determination of the economically acceptable system of road pricing from the perspective of carriers. By using such system it is possible to determine a toll rate threshold when the carrier prefers toll roads based on economic efficiency.

\section{Factors affecting carriers' decisions when planning a route of transport}

A route choice in road freight transport is the result of various factors that were addressed by several authors. These factors include, for example, route attributes, level of congestion, toll fees, fuel costs, time of carriage (travel time), speed, and vehicle operating costs. Table 1 summarises the results of studies which deal with the factors affecting a route choice.

Factors affecting a route choice made by transport companies [5], [6], [7], [8], [9] and [4]

Based on the results of processed studies, it can be stated that the most important factors are travel time, fuel costs and toll.

Travel time is the most important factor while deciding on a transport route, particularly because legislation stipulates the maximum driving time of drivers within a given period [10]. Table 2 provides a comparison of the stipulated working hours of drivers in individual countries. Maximum daily driving time

\footnotetext{
* ${ }^{1}$ Milos Poliak, ${ }^{\text {SStefania Semanova, }{ }^{2} \text { Salvador Hernandez, }{ }^{3} \text { Eliska Pastuszkova }}$

${ }^{1}$ Department of Road and Urban Transport, Faculty of Operation and Economics of Transport and Communications, University of Zilina, Slovakia

${ }^{2}$ School of Civil and Construction Engineering, Oregon State University, Corvallis, Oregon, USA

${ }^{3}$ Department of Finance and Accounting, Faculty of Management and Economics, Tomas Bata University in Zlin, Czech Republic

E-mail: milos.poliak@fpedas.uniza.sk
} 
Factors affecting a route choice made by transport companies [5], [6], [7], [8], [9] and [4]

\begin{tabular}{|l|c|c|c|c|c|c|}
\hline Authors of studies & $\begin{array}{c}\text { Knorring et al } \\
\text { (2005) }\end{array}$ & $\begin{array}{c}\text { Golob and } \\
\text { Regan (2001) }\end{array}$ & Bain (2002) & $\begin{array}{c}\text { Yalcin et al } \\
\text { (2005) }\end{array}$ & $\begin{array}{c}\text { Zyl and Raza } \\
\text { (2006) }\end{array}$ & $\begin{array}{c}\text { Vadali et al } \\
\text { (2007) }\end{array}$ \\
\hline Region & USA & $\begin{array}{c}\text { Los Angles } \\
\text { (USA) }\end{array}$ & $\begin{array}{c}\text { International } \\
\text { experience }\end{array}$ & Japan & $\begin{array}{c}\text { India, South } \\
\text { Africa }\end{array}$ & USA \\
\hline Driver's decision & & & & $\checkmark$ & $\checkmark$ & $\checkmark$ \\
\hline Manager's decision & & & $\checkmark$ & & & $\checkmark$ \\
\hline Driver wage / income & & & & & $\checkmark$ & $\checkmark$ \\
\hline Route attributes & $\checkmark$ & $\checkmark$ & & & $\checkmark$ & $\checkmark$ \\
\hline Congestion & & & & & & $\checkmark$ \\
\hline Toll & & $\checkmark$ & & & $\checkmark$ & $\checkmark$ \\
\hline Fuel costs & $\checkmark$ & $\checkmark$ & & $\checkmark$ & $\checkmark$ & $\checkmark$ \\
\hline Speed & & & & & $\checkmark$ & $\checkmark$ \\
\hline $\begin{array}{l}\text { Travel time } \\
\text { (reliability uncertainty) }\end{array}$ & & & $\checkmark$ & & & $\checkmark$ \\
\hline Vehicle operating costs & & & & & & $\checkmark$ \\
\hline
\end{tabular}

in individual countries is regulated in the interval from 9 hours in the EU to 15 hours in Canada (the northern part of the country, maximum daily driving time in the southern part of the country is 13 hours). Similarly, maximum weekly driving time or maximum driving time within two consecutive weeks is also regulated. Moreover, minimum daily and weekly rest period are stipulated in the analysed countries. Drivers cannot drive during the mentioned rest periods and a vehicle must be stationary if a driver draws the rest period in the vehicle.

When taking into account the mentioned restrictions, carriers prefer the shortest travel time due to the possibility to deliver the greatest number of shipments within the limited period of time, and from the reason of realisation of maximum vehicle performance that is possible within limited period of time. The mentioned statement was also stated in [4], [11], [12], [13] and [14]. This means that carriers will prefer a superior road infrastructure (toll roads) in terms of higher vehicle utilisation and they will be willing to pay the fees for its use unless the amount of fees is higher than the benefits associated with faster carriage performed on that infrastructure.
Fuel costs represent a significant cost item of the road freight transport operators. Table 3 provides the average proportion of fuel costs for the carriers operating in the USA compared to those operating in the EU. The proportion of fuel costs was at a comparable level of the total direct costs in the USA and the EU, in 2008; while the total direct costs did not contain the fees for using road infrastructure. Fuel costs represent a proportion of more than one third of the total direct costs of carriers. Two approaches arise when deciding on a transport route and ensuring the operation efficiency:

- In relation to variable costs - carrier prefers the shortest route of transport or transport route which does not lead through challenging mountain routes. If a shorter route leads through non-tolled infrastructure, carrier will prefer to use this route.

- In relation to fixed costs - carrier prefers the fastest transport route from the reason that fixed costs per unit are lower in the case of higher performance. Carrier prefers superior, faster, road infrastructure where probability of congestion formation is lower.

Regulation of driving time and rest period in individual analysed countries [15]

Table 2

\begin{tabular}{|l|c|c|c|c|c|}
\hline Requirement & EU & USA & Canada $^{1}$ & Australia & New Zealand \\
\hline Continuous driving time & $4.5 \mathrm{~h}$ & $8 \mathrm{~h}$ & $13 / 15 \mathrm{~h}$ & $5.25 \mathrm{~h}$ & $5.5 \mathrm{~h}$ \\
\hline Break & $45 \mathrm{~min}$ & $30 \mathrm{~min}$ & - & $15 \mathrm{~min}$ & $30 \mathrm{~min}$ \\
\hline Daily driving time & $9 \mathrm{~h}$ & $11 \mathrm{~h}$ & $13 / 15 \mathrm{~h}$ & $12 \mathrm{~h}$ & $13 \mathrm{~h}$ \\
\hline Daily rest period & $11 \mathrm{~h}$ & $10 \mathrm{~h}$ & $10 / 8 \mathrm{~h}$ & $7 \mathrm{~h}$ & $10 \mathrm{~h}$ \\
\hline Weekly driving time & $56 \mathrm{~h}$ & $70 \mathrm{~h}$ & $70 / 80 \mathrm{~h}$ & $72 \mathrm{~h}$ & $70 \mathrm{~h}$ \\
\hline Weekly rest period & $45 \mathrm{~h}$ & $34 \mathrm{~h}$ & $36 \mathrm{~h}$ & $24 \mathrm{~h}$ & $24 \mathrm{~h}$ \\
\hline Fortnightly driving time & $90 \mathrm{~h}$ & $148 \mathrm{~h}$ & $147 \mathrm{~h}$ & $144 \mathrm{~h}$ & $166 \mathrm{~h}$ \\
\hline
\end{tabular}


Proportion of individual costs on total costs of carrier in \% [Authors based on [16] and [17]]

Table 3

\begin{tabular}{|l|c|c|}
\hline Costs: & USA (2008) & EU (2008) \\
\hline Fuel & $36 \%$ & $37 \%$ \\
\hline Tires & $3 \%$ & $1 \%$ \\
\hline Maintenance and repairs & $9 \%$ & $8 \%$ \\
\hline Wage & $37 \%$ & $29 \%$ \\
\hline Depreciation & $12 \%$ & $18 \%$ \\
\hline Insurance & $4 \%$ & $7 \%$ \\
\hline Total & $100 \%$ & $100 \%$ \\
\hline
\end{tabular}

Toll costs are also an important factor affecting the use of toll road infrastructure by carriers during transport realisation. According to [16], the average costs of toll were at the level of 1.7 cents per mile $(\$ 0.0106 / \mathrm{km})$ for freight vehicles in the USA in 2011 . Toll costs represented about $1 \%$ of the total direct costs in that period of time. Toll fees represent a higher cost level within the EU. Table 4 provides an overview of toll rates in EU selected states. Given that toll rates in the EU depend on the total vehicle weight, number of axles as well as engine emission class of vehicle, the comparison in Table 4 is processed for a freight vehicle with a gross weight of 40 tons, 5 axles and emission class of EURO 5. Despite the fact that Directive No 1999/62/ EC determines a methodology for calculating toll rates, toll rates in the selected states are very different. For example, toll rate in Poland is at the level of $€ 0.050 / \mathrm{km}$, whereas toll rate in Austria is higher almost by $€ 0.3 / \mathrm{km}(€ 0.357 / \mathrm{km})$.

Comparison of toll rates in the selected states of the EU in euros/km (year 2013) [Authors based on [18], [19], [20], [21], [22] and [23]]

Overview of toll rates in EU

Table 4

\begin{tabular}{|l|c|}
\hline State & Toll $(\boldsymbol{€} / \mathbf{k m})$ \\
\hline Czech Republic & 0.150 \\
\hline Hungary & 0.289 \\
\hline Germany & 0.155 \\
\hline Poland & 0.050 \\
\hline Austria & 0.357 \\
\hline Slovakia & 0.189 \\
\hline
\end{tabular}

In the EU, costs of toll fees represent an average level of $€ 0.15 / \mathrm{km}$. Taking into account the average costs of the carriage by road freight transport $€ 1.2 / \mathrm{km}$, costs of toll fees in the EU represent the fourth most important cost item that follows the fuel costs, costs of vehicle acquisition (depreciation) and labour costs. It is necessary to note that toll rates in the EU are higher and they also represent a larger proportion on the total costs of carrier compared to the USA. Furthermore, it should be noted that likelihood of the use of parallel non-tolled infrastructure of lower category by the carrier is increasing with the increasing costs of toll. In the case of higher toll for using road infrastructure, the carrier is willing to endure a higher level of fuel costs (longer route) and unit fixed costs associated with the use of a parallel non-tolled road. However, the whole-society problem is that vehicle diversions from toll roads to non-tolled roads causes increased costs relating to congestion and traffic accidents which are growing in proportion with the increase of traffic intensity on non-tolled infrastructure. In times of economic recession in the USA in 2010, the fees for using road infrastructure decreased significantly. The objective was to motivate carriers to use toll roads because they had tendency to avoid the toll roads in order to reduce their own costs. Decline in the fees represented $43 \%$ compared to 2009 [16].

\section{Value of time savings in terms of road transport operators}

Main factors that affect the decision of carriers to use toll roads were identified in the previous chapter. Travel time is one of the most important factors. Value of time savings plays a key role related to the use of toll roads by carriers [24]. When considering the construction of toll infrastructure, public authorities should estimate how the carriers value their time savings associated with the use of toll infrastructure in terms of money. Only then it is possible to make a proper and efficient pricing policy.

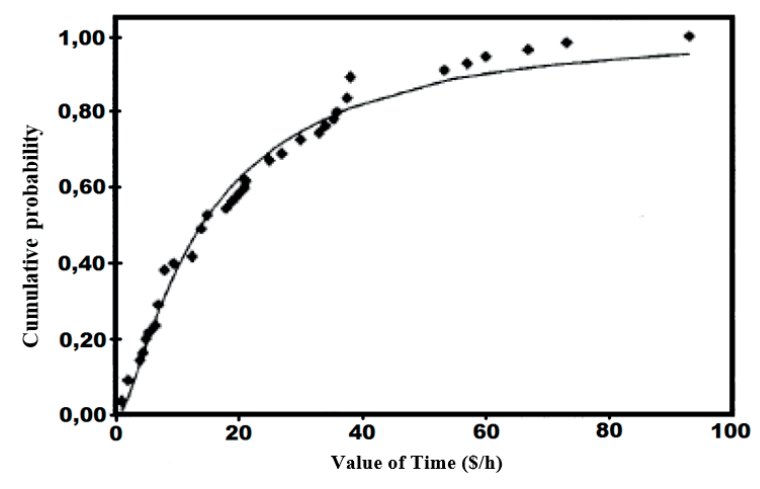

Fig. 1 Value of travel time savings for road transport companies in the USA [20]

Knorring, He and Kornhauser (2005) dealt with the value of time savings in terms of the carriers. They concluded that value of time savings is a key factor in a decision-making process of the carriers. They stated that the carriers, or drivers, do not just make a decision on which route to take when facing parallel routes, but every single transport route is planned with regard to the factor of time savings [5]. 
Several authors tried to estimate the value of time savings. Kawamura (2000) estimated this value based on preference data collected in California. Firstly, he summarised that value of time savings ranged from $\$ 14.50 /$ hour to $\$ 35.60 /$ hour according to the results of previous studies. Then, he estimated the mean value of time savings as $\$ 26.8 /$ hour based on own collected preference data. He also defined dependence of the likelihood of using a particular infrastructure on the value of time savings when using alternative transport route (Fig. 1). Likelihood of using a particular route is increasing with increasing value of time. At value of time savings of $\$ 100 / \mathrm{h}$, only low percentage of the carriers would not use a given infrastructure [25].

\section{Methodology proposal for determination of toll rates taking into account the value of time savings of road transport operators when using toll road infrastructure}

Superior road infrastructure, which is generally charged, is not built to ensure collection of funds for public budgets. According to [2], the main determinants for building a superior road infrastructure are:

- Intensity of road freight transport - main traffic flows should be realised within the superior road infrastructure outside the residential settlements.

- Accident rate - it is necessary to redeploy the volume of road traffic on the infrastructure of higher category in case of road infrastructure with high accident rate.

- Impact on the environment - the main traffic flows should be kept out of residential areas in order to improve life quality of the population.

Based on the mentioned assumptions, toll rate must be derived for individual sections based on the factors which affect the carriers' decision to realize transport by the use of a particular road infrastructure and not on the basis of construction costs of road infrastructure. Then it is possible to determine a methodology for calculating a maximum limit of price for using road infrastructure from the perspective of carriers.

To determine a maximum price limit of toll for the carrier, it is necessary to define the time $t_{S}$ as the time needed for distance travelled within toll road infrastructure $s_{S}$ at average speed achieved on this infrastructure $v_{S}$ :

$t_{S}=\frac{S_{S}}{v_{S}}(\mathrm{~h})$

The time $t_{N}$ needed for the distance travelled within non-tolled road infrastructure $s_{N}$ is calculated according to the following formula:

$t_{N}=\frac{s_{S}}{v_{N}}+k(\mathrm{~h})$ assuming that $v_{S}>v_{N}$ because toll road infrastructure is usually a superior road network with higher design speed compared to parallel non-tolled infrastructure. In relation (2), the value of time is increased by the factor $k$ whose value corresponds to the further delays related to the use of non-tolled road infrastructure (e.g. congestion related to transit through city, etc.).

Subsequently, time savings $\Delta t_{p}$ when using toll road infrastructure during the particular carriage can be determined as the difference between travel time for toll roads and travel time for non-tolled roads:

$\Delta t_{P}=t_{N}-t_{S}(\mathrm{~h})$

where $\Delta t>0$

The value of time savings for particular carriage $h_{P}$ is determined based on the unit value of time savings $h_{H}$ (determined according to the conditions of carrier per one hour) as follows:

$h_{P}=\Delta t_{P} \cdot h_{H}(€ /$ transport $)$

When deciding on a route choice, given that fuel costs represent a significant cost item, carriers also consider the fact that if two routes of carriage have different length, fuel cost savings arise in the case of a shorter one. Fuel costs $n^{P L}$ depend on the route length $s$, fuel consumption $s^{V}$ and the fuel price $c^{P L}$. This means that fuel costs expressed per 1 kilometre of distance travelled can be defined as a function:

$n^{P L}=f\left(s^{V}, c^{P L}\right)(€ / \mathrm{km})$

Given that vehicles perform less braking and acceleration when travelling on the superior road infrastructure and they usually do not go through challenging mountain routes, it can be concluded that fuel consumption is lower when driving on the road infrastructure of higher category. Thus, the following applies:

$S_{N}^{V}>S_{S}^{V}(1 / 100 \mathrm{~km})$

When comparing two possibilities of transport on the roads of different categories, it is necessary to take into account also cost savings associated with reduced fuel consumption of vehicle for considering savings in fuel costs on a particular route:

$n^{\Delta P L}=f\left(\Delta s^{V}, c^{P L}\right)(€ / \mathrm{km})$

where: $\Delta s^{V}=s_{N}^{V}-s_{S}$

While deciding between two possible routes, savings in fuel costs when using a toll road $n_{P}^{P L}$ can be calculated as:

$n_{P}^{P L}=\left(n^{P L}-n^{\Delta P L}\right) \cdot \Delta s(€ /$ transport $)$ 
where: $\Delta s=s_{N}-s_{S}$

When comparing savings in fuel costs while deciding between toll infrastructure and non-tolled infrastructure, it is necessary to take into account the assumption that a transport route with the use of toll infrastructure can be shorter or longer compared to a route with the use of only non-tolled infrastructure. This means that the following applies: $\Delta s \in R$.

The costs for using toll road infrastructure from the perspective of carrier $n_{a}$ are dependent on the rate per kilometre travelled $a_{S}$ and distance travelled on the toll road $s_{S}$ :

$n_{a}=s_{S} \cdot a_{S}(€ /$ transport $)$

If costs for using toll road infrastructure are at such a level that the carrier is willing to use this infrastructure, the following will have to be applied:

$n_{a} \leq n_{P}^{P L}+h_{P}(€ /$ transport $)$

From the above equation, it is possible to determine the maximum toll rate at which the toll road infrastructure will be preferable from the perspective of the carrier:

$a_{S}=\frac{\left(n^{P L}-n^{\Delta P L}\right) \cdot \Delta s+\Delta t_{P} \cdot h_{H}}{S_{S}}(€ / \mathrm{km})$

Elaborated methodology for determination of acceptable level of toll rate is based on the requirement for preference of toll road infrastructure by the freight transport operator. The rates can be determined for different vehicle categories similarly like current rate structure in the EU. For example, a special rate for vehicles with a gross weight between $3.5 \mathrm{t}$ and $12 \mathrm{t}$ and a special rate for vehicles over $12 t$ of total weight. The methodology does not take into account the return on funds related to infrastructure construction and also the cost reductions related to:

- Reduction of the accident rate for non-tolled infrastructure of lower categories;

- Reduction of congestion for non-tolled infrastructure;
- Reduction of the impact on the environment by dust and fumes within area of towns and villages.

\section{Conclusion}

The situation where freight vehicles which bypass toll road infrastructure and use non-tolled infrastructure of lower category still persists in EU countries. However, these non-tolled roads often lead across populated areas such as towns and villages. Operators of road freight transport prefer non-tolled road infrastructure in order to reduce their costs related to vehicle operation in the case that costs of fees for using toll infrastructure exceed the effects associated with the use of this infrastructure, e.g. in the form of time savings or savings in fuel costs. Under EU legislation, the level of fee for using road infrastructure is dependent on the costs of its construction and maintenance without assessment of the impact of such determined fee on the demand of operators for the use of toll infrastructure. Public authorities then look for solutions of transit restrictions for road freight transport on parallel non-tolled roads. However, these solutions are often not effective without a thorough inspection. It is also difficult to ensure effective control between transport service of territory and transit of territory. Therefore, a suitable solution is to set the level of fee for the use of road infrastructure so that carriers can use toll road infrastructure more efficiently. Approach to determination of toll rates mentioned in this paper is based on time savings and savings in carriers' fuel costs. At such determined rates, decrease in costs expended from public budgets can be expected. These costs particularly include costs for controls of transit on nontolled infrastructure, costs associated with the accident rate, the impact on the environment and congestion.

\section{Acknowledgement}

This paper was developed under the support of project: MSVVS SR - VEGA No. 1/0320/14 POLIAK, M.: Zvysovanie bezpecnosti cestnej dopravy prostrednictvom podpory hromadnej prepravy cestujucich.

\section{References}

[1] POLIAK, M.: Impact of Road Network Charging System on Pricing for General Cargo Transportation, PROMET - Traffic \&Transportation - Scientific J. on Traffic and Transportation Research, vol. 24, No. 1, 2012, pp. 25-33.

[2] POLIAK, M., KONECNY, V.: Factors Determining the Extent of Charging of Road Infrastructure by Using Electronic Toll (in Slovak), Ekonomicky casopis - J. of Economics, vol. 56, No. 7, 2008, pp. 712-731.

[3] POLIAK, M.: The Introduction of Electronic Toll from the Perspective of Road Transport Operator (in Slovak), ITS intern. conference in Bratislava, 10.-11. 9. 2008.

[4] VADALI, S. R., GUPTA, R. S., WOMACK, K. N., AND PAPPU, M.: Trucking Industry Responses in a Changing World of Tolling and Rising Fuel Prices, SWUTC/07/167167-1 - Texas Transportation Institute: Texas A\&M University System: College Station, TX, 2007. 
[5] KNORRING, J. H., HE, R., KORNHAUSER, A. L.: Analysis of Route Choice Decisions by Long-Haul Truck Drivers, Proc. of Transportation Research Board Annual Meeting, 2005.

[6] GOLOB, T. G., REGAN, A. C.: Impacts of Highway Congestion on Freight Operations: Perceptions of Trucking Industry Managers, Transportation Research Part A, vol. 35, 2001, pp. 577-599.

[7] BAIN, R.: Credit Implications of Traffic Risk in Start-Up Toll Facilities, Infrastructure Finance, Standard \& Poor's: London, 2002.

[8] YALCIN, A., HASHIUCHI, J. AND MIZOKAMI, S.: A Study on Expressway Toll Pricing Based on the Results of Social Experiment, TRB 85 $5^{\text {th }}$ Annual Meeting CD ROM, 2005.

[9] ZYL, N. J. W. V., RAZA, M.: In Search of the Value of Time: From South Africa to India, Travel Survey Methods: Quality and Future Directions, Elsevier Science, pp. 457-484, 2006.

[10] NOSAL, K.: How to Change the Travellers' Mobility Behaviours? - Examples of Mobility Plans. Communications - Scientific Letters of the University of Zilina, No. 4, 2009, pp. 52-55.

[11] CETIN, U., INCE, N., BAYINDIR, P., SAVASANERIL, S.: Route Selection and Scheduling for Urban Public Bus Transportation. Communications - Scientific Letters of the University of Zilina, No. 1, 2013, pp. 19-24.

[12] FAITH, P.: Passenger Road Transport Trends in the Slovak Republic. Communications - Scientific Letters of the University of Zilina, No. 3, 2008, pp. 33-39.

[13] POLIAKOVA, A.: Customer Satisfaction Index with a Quality of Service in Public Mass Transport, Transport and Communications, No. 2, 2010, pp. 43-49.

[14] GeISELBRECHT, T., BURRIS, M., BAKER, T., ZHOU, L., WALTMAN, M., MONTES, J.: State Highway 130 value Pricing Project for the Austin District, Prepared for Texas Transportation Institute: College Station, TX, 2008.

[15] POLIAK, M.: Social Legislation and its Impact on Pricing in Road Transport (in Slovak), Perner's Contacts [electronic source], vol. 9, No. 3, 2014, pp. 169-178, available: 〈http://pernerscontacts.upce.cz/36_2014/Poliak.pdf>

[16] Fender, K. J., Pierce, D. A.: An Analysis of the Operational Costs of Trucking, 2012, available <http://www.glostone.com/wp-content/ uploads/2012/09/ATRI-Operational-Costs-of-Trucking-2012.pdf>.

[17] KONECNY, V., POLIAK, M., POLIAKOVA, A.: Economic Analysis of a Road Transport Company (in Slovak), University of Zilina, 2010

[18] Toll in the Czech Republic, <http://www.mytocz.eu/sk/mytny-system-2/sadzby-myta/index.html> (01. 07. 2013).

[19] Toll in Hungary, <http://toll-charge.hu/Electronic-toll/Pricing/> (03. 07. 2013).

[20] Toll in Germany, <http://www.toll-collect.de/en/all-about-the-toll/toll-rates.html> (03. 07. 2013).

[21] Toll in Poland, <http://www.viatoll.pl/sk/vozidla-nad-3-5-t/sadzobnik-poplatkov> (01. 07. 2013).

[22] Toll in Austria, <https://www.go-maut.at/portal/portal> (01. 07. 2013).

[23] Toll in the Slovak Republic, <https://www.emyto.sk/web/guest/toll/rates> (03. 07. 2013).

[24] KAlAsovA, A., CERNiCKY, L., KUBIKOVA, S.: Microscopic Simulation of Coordinated Route in the City of Zilina. Communications - Scientific Letters of the University of Zilina, No. 2, 2014, pp. 46-50.

[25] KAWAMURA, K.: Perceived Value of Time for Truck Operators, Transportation Research Record, vol. 1725, Transportation Research Board, National Research Council: Washington, DC, 2000. 